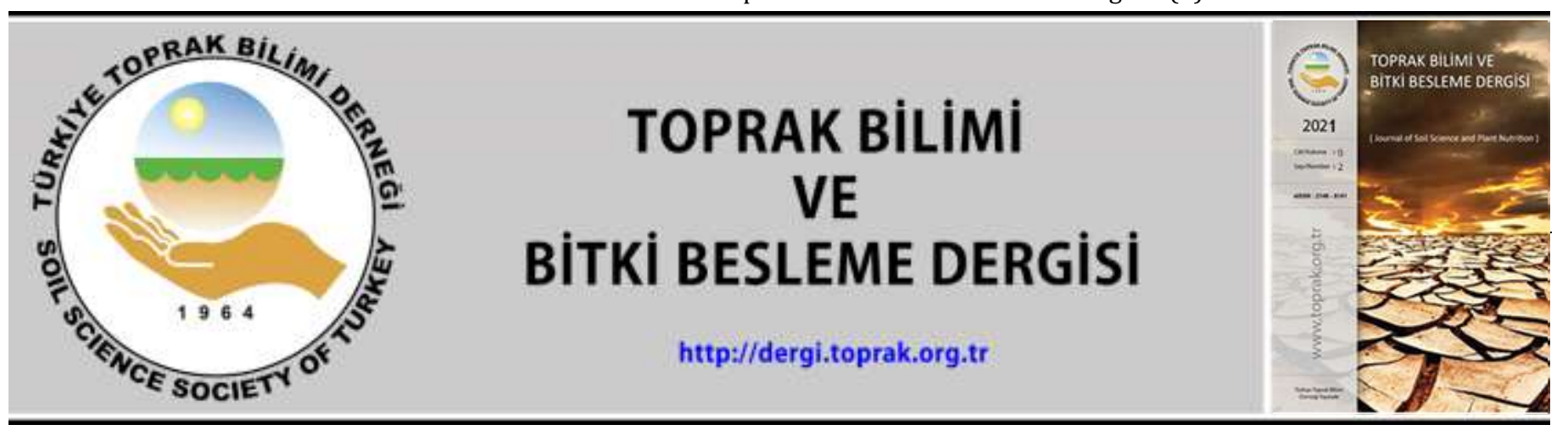

\title{
Yarı-kurak tepe-eğim (hillslope) bir arazide hidropedolojik değişkenlerin faktör analizi ${ }^{\dagger}$
} Seval Sünal Kavaklıgil1*, ๑Ülkü Yılmaz1, ๑Sabit Erşahin²

\author{
${ }^{1}$ Çankırı Karatekin Üniveristesi Orman Fakültesi, Çankırı \\ 2Iğdır Üniversitesi, Ziraat Fakültesi, Toprak Bilimi ve Bitki Besleme Bölümü
}

\begin{abstract}
Özet
Toprak özellikleri doğal süreçler, çevresel etmenler ve farklı amenajman uygulamaları sonucu dikey ve yatay yönde değişmektedir. Toprak değișkenliğinin değerlendirilmesinde çok sayıda yöntem kullanılmakta olup, her yöntemin avantajları ve dezavantajları vardır. Bu çalışma ile Çankırı'da 82 hektarlık yarı kurak bir alanda toprak varyasyonu faktör analizi ile değerlendirilmiştir. Tepeeğim (hillslope) modelinin her bir pozisyonundan alınan toplam 486 toprak örneği faktör analizi ile tanımlanmıştır. Bu sebeple 27 toprak parametrik ve morfometrik değișkeni kullanılmıştır. Yapılan analiz sonucuna göre Scree analizine dayalı olarak dokuz faktör seçilmiş olup, bu faktörler veri setindeki toplam varyansın \%75,4'ünü açıklamıștır. Gözenek ve kök miktar/boyut/şeklinin yüklendiği faktör 1, çalışma alanı verilerinin varyasyonun en büyük yüzdesi (\%18.1) olduğunu göstermiştir. Çıkan sonuca göre, çalışma alanında gözenek ve kök özelliklerinin, hidropedolojik özelliklerin varyasyonunu kontrol eden en önemli değișken olduğunu göstermiştir.
\end{abstract}

Anahtar Kelimeler: Faktör analizi, yarı-kurak tepe-eğim, toprak morfolojik özellikleri, hidropedoloji

\section{Factor analysis of hydropedological variables on a semi-arid hillslope}

\begin{abstract}
Soils are highly spatially variable due to natural and management factors. Numerous of methods are used in evaluation of soil variability, each method has its advantages and disadvantages. We evaluated soils variation in a 82-ha cultivated semi-arid area in Cankırı by factor analysis. We used 27 soil parametric and morphometric variables, described on 486 sites at different positions of hillslopes with various aspects, with factor analysis. It were selected nine factors based on scree analysis. The nine factors explained $75.4 \%$ of total variance in dataset. The factor 1, in which quantity, size, shape of roots and pores were loaded, explained greatest percent of variation $(18.1 \%)$ in data, and this suggested the pore and root propertied were the most important variables controlling variation of hydropedological properties in the study area.
\end{abstract}

Keywords: Factor analysis, semi-arid hillslope, spatial variation, soil morphologic properties

(C) 2021 Türkiye Toprak Bilimi Derneği. Her Hakkı Saklıdır

\section{Giriş}

Toprak özellikleri doğal süreçler, çevresel etmenler ve farklı amenajman uygulamaları sonucu dikey ve yatay yönde değişmektedir. Toprak özellikleri ve bunların peyzaj üzerindeki dağılımı, uzun zamandır hidrolojik süreçler için kritik olarak kabul edilmektedir. Toprağın hidrolojik süreçler üzerindeki etkisi, toprağın suyu iletme, depolama ve reaksiyona girme yeteneğinden kaynaklanmaktadır (Park ve Burt, 1999). Yarı-kurak bölgelerde infiltrasyon hızı ve hidrolik iletkenlik gibi hidrolojik süreçler zamansal ve mekansal olarak fazla değişkenlik gösterirler. Bu bölgelerde hidrolojik süreçler ve etki mekanizmaları bilindiği taktirde bu süreçlerin modellenmesi ve kontrol edilmesi daha kolay olur (Mayor ve ark., 2009). Hidrolojik süreçleri gözlemlemek ve ölçmek oldukça zor ve maliyetlidir. Bu süreçler doğada dinamik olup, kuvvetli zamansal ve uzaysal değişkenlik göstermektedir (Sivapalan, 2003). Uzaysal ve zamansal değişkenliğin toprak üzerindeki

\section{* Sorumlu yazar:}

Tel. : : 03762120519

E-posta : sevalsunal@karatekin.edu.tr
Makale Türü: ARAŞTIRMA MAKALESI (†ilk yazarın doktora tezinden üretilmiştir) Geliș Tarihi : 17 Ağustos 2021 e-ISSN : 2146-8141

Kabul Tarihi : 03 Kasim $2021 \quad$ DOI $\quad 10.33409 /$ tbbbd.983787


etkilerinin anlaşılması için uzun vadeli ölçümler gerekir ancak toprak özellikleri hem kısa vadede doğada dinamik değildir hem de uzaysal değişkenliği rastgele değildir (Webster ve Oliver, 2001).

Toprak değişkenliğinin değerlendirilmesinde çok sayıda yöntem kullanılmakta olup, her yöntemin avantajları ve dezavantajları vardır. Faktör analizi birbiriyle ilişkili olan çok sayıdaki değişkeni kullanarak daha az sayıda, anlamlı ve birbirinden bağımsız faktörler haline getirmeye yarayan bir istatistik tekniğidir (Nizam ve ark., 1998; Sağlam, 2013). Bu yöntem ile veri setindeki maksimum bilgi sağlayan değişkenler belirlenerek (McNeal ve ark., 1985), elde edilen bilgiler ıșığında toprakların sınıflandırılması ve amenajmanında yaygın olarak kullanılabilir (Donkin ve Fey, 1991; Sánchez-Marañón ve ark., 1996). Toprak özelliklerinin değişkenliğinin belirlendiği birçok çalışmada faktör analizinin kullanıldığı görülmektedir (Erşahin ve Karaman, 2000; McGrath ve ark., 2004; Sağlam, 2013, 2015; Shukla ve ark., 2006). Bu çalışmada tipik yarı-kurak özellik gösteren, jips ve kireç depozitleri üzerinde yer alan arazinin toprak morfolojik, fiziksel ve kimyasal özellikleri, infiltrasyon ve doymuş hidrolik iletkenlik gibi birbirleriyle etkileşim halindeki özelliklerin çalışma alanındaki etkileșimleri incelenmiştir. Çalışmada birbiriyle ilişkili çok değişkenin olması sebebiyle, bu değişkenleri kullanarak daha az sayıda, anlamlı ve birbirinden bağımsız faktörler elde edebilmek için faktör analizi yapılmıştır.

\section{Materyal ve Yöntem}

Araştırma Çankırı ili Aşağı Pelitözü Köyü'nün 4 km güney doğusunda bulunan tarım arazilerinde yürütülmüştür (Şekil 1). Çalışma alanı toplam 82 ha'dır. Çalışma alanında yayılış gösteren anakaya jips olup, tabanda kum taşı, silt taşı, üste doğru kil taşı ve marn ara bantları kapsar. Çalışma alanı ve çevresi Türkiye'de özellikle Oligo-Miosen jipsli serileri olarak bilinen formasyonların yaygın olarak bulunduğu sahalardandır (Doğan, 2002). Çalışma alanının nem rejimi 'Xeric', toprak sıcaklık rejimi ise 'Mesic'tir.

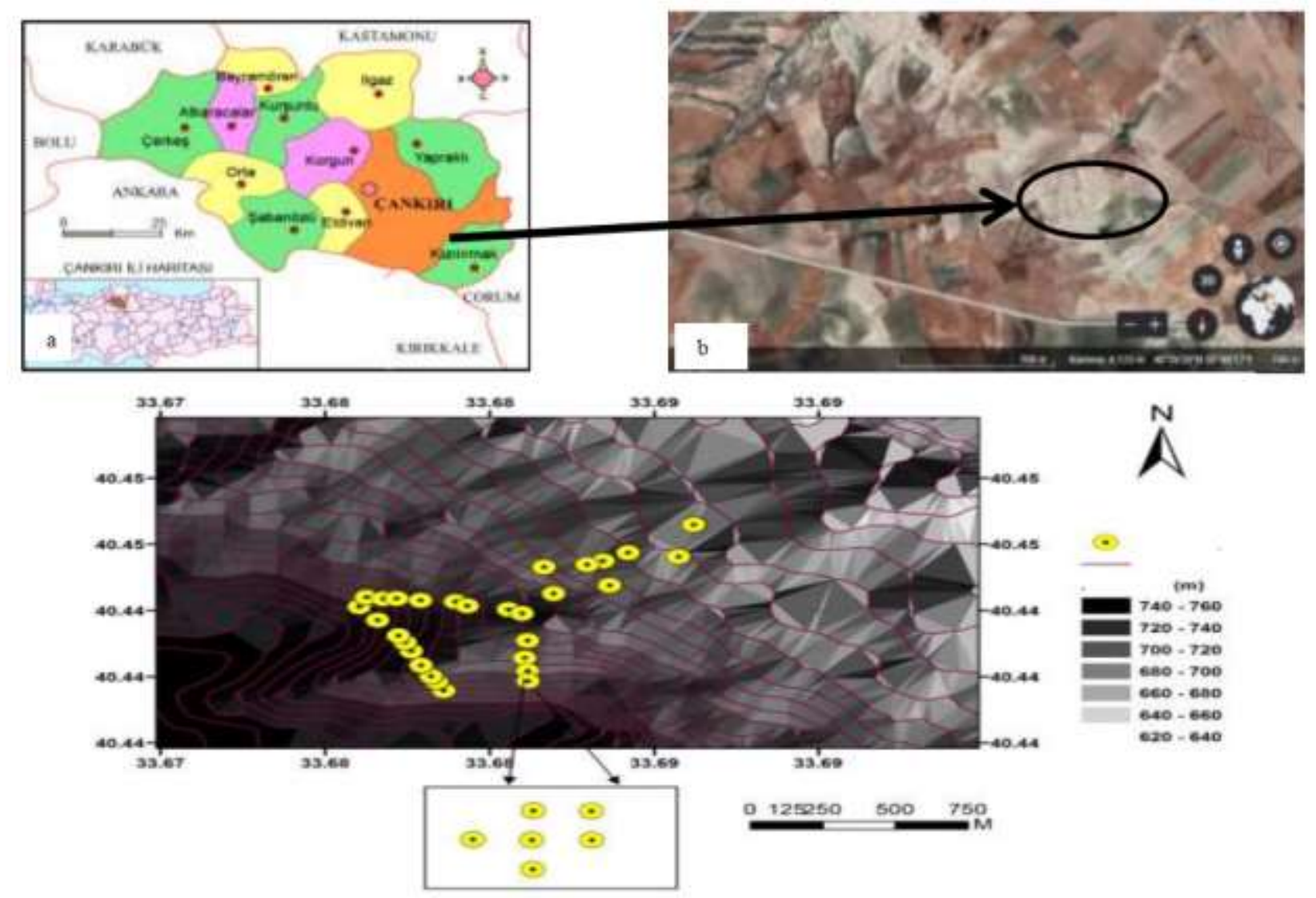

Şekil 1. Çalışma alanının konumu, toprak profilleri ve örnekleme noktalarının çalışma alanındaki konumları (a ve b Anonim, 2021).

Çalışma alanı tipik karasal iklim özellikleri göstermektedir (Birgili ve ark., 1975). Çalışma alanına en yakın meteoroloji istasyonu Çankırı merkezdedir. Çankırı Meteoroloji İstasyonundan (731 m) alınan verilere göre; bölgede yıllık ortalama sıcaklık $11.3^{\circ} \mathrm{C}$ 'dir. En yüksek sıcaklık $31.2^{\circ} \mathrm{C}$ ile Ağustos ayında, en düşük sıcaklık $4.0^{\circ} \mathrm{C}$ ile Ocak ayında gerçekleşmiştir. Yıllık ortalama yağış miktarı $412.3 \mathrm{~mm}$ 'dir. Çalışma tepe-eğim 
modelinin (hillslope) beş farklı pozisyonunda (zirve eğim, omuz eğim, arka eğim, ayak eğim, parmak eğim) yürütülmüștür. Çalıșma alanında her bir tepe-eğim pozisyonu için ölçümler yapılmıș ve aynı zamanda bir kepçe ile her pozisyonu temsilen 31 adet toprak profili açılmıştır. Açılan her toprak profilinde horizonlarda derinlik, kalınlık, horizonlar arası sınır, horizonun tekstürü ve strüktürü, rengi, kıvamı, köpürme, kök dağılımı, taşlılık, gözeneklilik, redoximorfik özellikler, eğim sınıfı-derecesi, ana materyal, plastiklik, yapışkanlık, dağılganlık, yüzey özellikleri, toprak çatlakları ve özel görünümler tanımlanarak not edilmiştir. Toprak morfolojik özelliklerinin tanımlanması "Field Book For Describing and Sampling Soils. 2012 version 3. National Soil Survey Center, Natural Resources Conservation Service U.S. Department of Agriculture" de belirtildiği şekilde yapılmıştır.

Toprak örneklerinin alındığı bölgeyi temsilen tansiyon infiltrometresi ile infiltrasyon ölçümleri ve horizon esasına göre de Guelph permeametresi ile hidrolik iletkenlik ölçümleri yapılmıştır. Bu bağlamda 495 adet hidrolik iletkenlik testi, 155 adet infiltrasyon testi yapılmış olup, toplam 486 adet toprak örneği alınmıştır. İnfiltrasyon hızının belirlenmesinde kullanımı hızla yaygınlaşan tansiyon infiltrometreleri kullanılmıștır. Guelph permeametresinin kullanımı ise detaylı olarak araştırmacılar tarafından tanımlanmıştır (Reynolds ve Elrick, 1985). Çalışma alanının genel özelliklerini belirlemek amacıyla toprak tekstürü (Gee ve Bauder, 1986), agregat stabilitesi (Kemper ve Rosenau, 1986), pH (Hendershot ve ark., 1993), elektriksel iletkenlik (Janzen, 1993), toprak organik maddesi (Nelson ve Sommers, 1982), kireç miktarı (Kacar, 1996), tarla kapasitesi, solma noktası (Cassel ve Nielsen, 1986), hacim ağırlığı (Blake ve Hartge, 1986) ve katyon değişim kapasitesi (Chapman ve Pratt, 1982) analizleri yapılmıştır.

Çalışma alanından horizon esasına göre alınan toprak örneklerinin analiz sonuçları kullanılarak toprak özelliklerinin genel durumunu ve değişimini değerlendirmek için tanımlayıcı istatistikler yapılmıştır. Toprak morfolojik özelliklerini sayısal olarak değerlendirebilmek için kodlama sistemi yapılmıștır (Tablo 1). Her bir toprak morfolojik özelliği için ayrı ayrı numaralar verilerek tanımlayıcı istatistikleri yapılmıştır. Çalışma alanında fazla sayıda değişken olmasından dolayı veri setini basitleștirmek ve toprak değişkenliğinin genel dağılımında etkili olan faktörleri belirleyebilmek için çok değişkenli istatistiksel analiz olan faktör analizi yapilmıştır.

Çizelge 1.Toprak morfolojik özelliklerinin kodlanması

\begin{tabular}{|c|c|c|c|c|c|}
\hline \multicolumn{2}{|c|}{ Benekleşme } & \multirow{2}{*}{$\begin{array}{c}\text { Yapısskanlık } \\
\text { Yapışkan değil }\end{array}$} & \multirow{2}{*}{$\begin{array}{c}\text { Kod } \\
1\end{array}$} & \multirow{2}{*}{$\begin{array}{c}\text { Plastiklik } \\
\text { Plastik değil }\end{array}$} & \multirow{2}{*}{$\begin{array}{c}\text { Kod } \\
1\end{array}$} \\
\hline Miktar/Büyüklük & Kod & & & & \\
\hline Yok & 0 & Az yapışkan & 2 & Az plastik & 2 \\
\hline Az-kaba & 1 & Orta yapıșkan & 3 & Orta plastik & 3 \\
\hline Yaygın-orta & 2 & Çok yapışkan & 4 & Çok plastik & 4 \\
\hline Çok-kaba & 3 & & & & \\
\hline \multicolumn{6}{|c|}{ Kökler ve Gözenekler } \\
\hline Sinıf & Kod & Boyut & Kod & Şekil & Kod \\
\hline $\mathrm{Az}$ & 1 & Çok ince & 1 & Dendritik & 1 \\
\hline Yaygın & 2 & İnce & 2 & Düzensiz & 2 \\
\hline \multirow[t]{3}{*}{ Çok } & 3 & Orta & 3 & Tüp şeklinde & 3 \\
\hline & & Kaba & 4 & Dağınık & 4 \\
\hline & & Çok kaba & 5 & & \\
\hline \multicolumn{6}{|c|}{ Konkresyon-Nodül (Konsantrasyon) } \\
\hline Sinif & Kod & Boyut & Kod & Şekil & Kod \\
\hline Yok & 0 & Yok & 0 & Silindirik & 1 \\
\hline $\mathrm{Az}$ & 1 & İnce & 1 & Dendritik & 2 \\
\hline Yaygın & 2 & Orta & 2 & Düzensiz & 3 \\
\hline \multirow[t]{3}{*}{ Çok } & 3 & Kaba & 3 & Yassı & 4 \\
\hline & & Çok kaba & 4 & A ̆ğımsı & 5 \\
\hline & & Fazla kaba & 5 & Küresel & 6 \\
\hline \multicolumn{6}{|c|}{ Pedalite } \\
\hline Tip & Kod & Sinıf & Kod & Boyut & Kod \\
\hline Granüler & 1 & Zayıf & 1 & Çok ince & 1 \\
\hline Köșeli blok & 2 & Orta & 2 & İnce & 2 \\
\hline Yarı-köşeli blok & 3 & Güçlü & 3 & Orta & 3 \\
\hline Yassı & 4 & & & Kaba & 4 \\
\hline Tabakalı & 5 & & & Çok kaba & 5 \\
\hline Prizmatik & 6 & & & Çok fazla kaba & 6 \\
\hline Kolumnar & 7 & & & & \\
\hline
\end{tabular}




\section{Bulgular ve Tartışma}

Çalışma alanına ilişkin toprak özelliklerinin tanımsal istatistikleri Çizelge.1'de verilmiştir. Çalışma alanı toprakları organik maddece fakir $(1,73)$, kireçli $(\% 22,5)$, tuzsuz (EC: 0,69 dS/m) ve alkalin (pH: 8,28) dir. Toprakların ortalama kil içeriği \% 42,1, kum içeriği \% 31,1 ve silt içeriği \% 26,8'dir (Çizelge 1). Çalışma alanındaki toprak tekstürü genellikle kumlu kildir. Çalışma alanı topraklarının pH'sı 7,45-8,79 arasında değişmektedir. Çalışma alanında $\mathrm{K}_{\mathrm{s}}$ için aritmetik ortalama 2,21 (cm/s), en küçük değer 0,01 (cm/s) ve en büyük değer de 14,19 (cm/s) olarak bulunmuştur. Çalışma alanında ölçülen toprak özelliklerinin değişkenliklerini birbiri ile kıyaslayabilmek için varyasyon katsayılarına bakıldığında, en yüksek EC, agregat stabilitesi ve doymuş hidrolik iletkenliğin $\left(K_{s}\right)$ değișkenlik gösterdiği (sırasıyla \%94,6, \%102,5, \%109,5), pH'nın ise düşük düzeyde değişkenlik gösterdiği $(\% 2,41)$ görülmektedir. pH'nın az değişkenlik göstermesini yapılan diğer çalışmalar da desteklemektedir (Erşahin, 1999a; Mulla ve McBratney, 2000). Bu sonuca göre $\mathrm{pH}$, arazi boyunca daha fazla benzerlik gösterirken, EC'nin ise aşırı farklılık gösterdiği yorumu yapılabilir. Çizelge 1'e göre araştırma alanı topraklarının $\mathrm{K}_{s}$ ortalaması $0,00071 \mathrm{~cm} / \mathrm{s}$ çıkmıştır. Bu değer $\mathrm{K}_{s}$ sınıflandırmasında çok düşük sınıfına girmektedir (Klute ve Dirksen, 1986). Elde edilen sonuçlara göre, en fazla değişkenlik gösteren (VK= 109,5) toprak özelliklerinden bir tanesi de $K_{s}$ (doymuş hidrolik iletkenlik)'dir (Çizelge.1). Bu değişkenliğin, çalışma alanındaki yersel topoğrafik farklılıklar ile toprak işleme ve tekstürdeki farklılıkların $K_{s}$ üzerinde yaptığı etkiden kaynaklandığı düşünülmektedir.

Çizelge 1. Çalışma alanı topraklarının parametrik ve morfolojik özelliklerine ilişkin tanımsal istatistik analiz sonuçları $(\mathrm{N}: 486)$

\begin{tabular}{|c|c|c|c|c|c|c|c|c|c|}
\hline Değișkenler & $\begin{array}{l}\text { Örnek } \\
\text { sayısı }\end{array}$ & En Küçük & En Büyük & Ortalama & $\begin{array}{l}\text { Standart } \\
\text { sapma }\end{array}$ & Varyans & Çarpıklık & Basıklık & $\begin{array}{c}\text { Varyasyon } \\
\text { Katsayısı } \\
\text { (VK) }\end{array}$ \\
\hline TOM (\%) & 486 & 0,03 & 3,67 & 1,73 & 0,85 & 0,73 & 0,10 & $-0,83$ & 49,13 \\
\hline $\mathrm{Db}\left(\mathrm{g} / \mathrm{cm}^{3}\right)$ & 486 & 1,00 & 1,55 & 1,27 & 0,13 & 0,02 & 0,11 & $-1,04$ & 10,20 \\
\hline$\neq \operatorname{Nem}(\%)$ & 486 & 1,39 & 34,11 & 14,96 & 7,41 & 54,9 & 0,10 & $-0,71$ & 49,53 \\
\hline $\mathrm{CaCO}_{3}(\%)$ & 486 & 3,64 & 68,00 & 22,53 & 8,81 & 77,68 & 0,98 & 1,97 & 39,10 \\
\hline $\mathrm{EC}(\mu \mathrm{S} / \mathrm{cm})$ & 486 & 10.00 & 2180 & 690,0 & 652,93 & 426322,8 & 1,15 & $-0,06$ & 94,62 \\
\hline $\mathrm{pH}$ & 486 & 7,45 & 8,79 & 8,28 & 0,20 & 0,04 & 0,12 & 0,08 & 2,41 \\
\hline Kum (\%) & 486 & 7,20 & 67,00 & 31,13 & 12,08 & 146,04 & 0,76 & 0,03 & 38,80 \\
\hline Kil (\%) & 486 & 0,80 & 74,30 & 42,05 & 19,03 & 362,33 & $-0,51$ & $-0,86$ & 45,25 \\
\hline Silt (\%) & 486 & 0,90 & 73,40 & 26,86 & 15,40 & 237,32 & 1,08 & 0,85 & 57,33 \\
\hline Agregat Stabilitesi (\%) & 486 & 0,02 & 10,99 & 2,00 & 2,05 & 4,22 & 1,58 & 2,35 & 102,5 \\
\hline TK $(\%)$ & 486 & 11,75 & 53,29 & 32,86 & 6,65 & 44,27 & 0,17 & 0,20 & 20,23 \\
\hline SN (\%) & 486 & 5,13 & 33,09 & 21,50 & 4,98 & 24,81 & $-0,60$ & 0,37 & 23,16 \\
\hline BYSİ (\%) & 486 & 0,28 & 35,01 & 11,22 & 6,29 & 39,63 & 0,60 & 0,22 & 56,06 \\
\hline $\mathrm{K}_{\mathrm{s}}(\mathrm{cm} / \mathrm{s})$ & 486 & 0,01 & 14,19 & 2,21 & 2,42 & 5,90 & 2,43 & 6,96 & 109,50 \\
\hline KDK (meq/100gr) & 486 & 1,13 & 41,56 & 24,4 & 10,03 & 100 & $-0,46$ & $-0,93$ & 41,10 \\
\hline Sorptivite $\left(\mathrm{cm} / \mathrm{sn}^{0.5}\right)$ & 174 & 0,19 & 16,40 & 2,20 & 2,80 & 7,87 & 2,46 & 6,41 & 127,00 \\
\hline İnfiltrasyon Hızı $(\mathrm{cm} / \mathrm{sa})$ & 174 & 0,10 & 11,18 & 3,35 & 2,81 & 7,92 & 0,80 & $-0,43$ & 83,88 \\
\hline Benekleşme & 81 & 0,00 & 3,00 & 0,24 & 0,68 & 0,46 & 2,57 & 5,27 & 283,30 \\
\hline $\begin{array}{l}\text { Konsantrasyonlar } \\
\text { (Konkresyon-nodüll }\end{array}$ & 81 & 0,00 & 20,00 & 5,11 & 5,90 & 34,82 & 0,97 & $-0,37$ & 115,45 \\
\hline $\begin{array}{l}\text { Pedalite } \\
\text { Pellons }\end{array}$ & 81 & 1,00 & 22,00 & 7,24 & 5,38 & 29,03 & 0,73 & 0,16 & 74,30 \\
\hline Kırılganlık & 81 & 1,00 & 19,00 & 7,65 & 4,64 & 21,55 & 0,46 & $-0,96$ & 60,65 \\
\hline Yapışkanlık & 81 & 1,00 & 4,00 & 2,00 & 0,79 & 0,62 & 0,15 & $-0,97$ & 39,50 \\
\hline Plastiklik & 81 & 1,00 & 4,00 & 2,01 & 0,74 & 0,56 & 0,16 & $-0,70$ & 36,81 \\
\hline Gözenek Sınıfı & 81 & 0,00 & 3,00 & 1,06 & 0,59 & 0,35 & 0,33 & 0,96 & 55,60 \\
\hline Gözenek Boyutu & 81 & 0,00 & 5,00 & 1,37 & 0,99 & 0,98 & 1,15 & 1,88 & 72,20 \\
\hline Gözenek Şekli & 81 & 0,00 & 4,00 & 1,34 & 1,05 & 1,10 & 1,18 & 0,79 & 78,30 \\
\hline Kök Sınıfı & 81 & 0,00 & 3,00 & 1,07 & 0,59 & 0,35 & 0,33 & 0,96 & 55,10 \\
\hline Kök Boyutu & 81 & 0,00 & 5,00 & 1,40 & 0,99 & 0,99 & 1,03 & 1,63 & 70,70 \\
\hline Kök Șekli & 81 & 0,00 & 4,00 & 1,34 & 1,05 & 1,10 & 1,18 & 0,79 & 78,30 \\
\hline
\end{tabular}

TOM: Toprak Organik Maddesi, Db: Hacim Ağırlı̆̆ı, = Örnekleme Anındaki Su İçeriği, AS: Agregat Stabilitesi, TK: Tarla Kapasitesi, SN: Solma Noktası, BYSİ: Bitkiye Yarayışlı Su İçeriği, Ks: Doymuş Hidrolik İletkenlik, KDK: Katyon Değişim Kapasitesi, İH: İnfiltrasyon Hızı

Çalışmamızda faktör analizi toprak özelliklerinin kendi aralarındaki ilişkileri ortaya koymak için kullanılmıştır. Faktör analizi korelasyon matrisi kullanılarak değişkenler üzerinde faktör yükünün belirlenebilmesi için kullanılmaktadır (Çelenk, 2016). Öz değeri 1'den büyük faktörler veri içerisinde her bir toprak özelliğinden daha fazla toplam değişkenliği açıklar. Öz değeri 1'den küçük faktörler de her bir toprak 
özelliğine göre daha düşük toplam değişkenliği ifade eder. Bu sebeple sadece 1'den büyük faktörler dikkate alınır ve toprak özellikleri en yüksek öz değere sahip olan faktörlere atanırlar (Çelenk, 2016). Faktör analizinde çizgi grafiğinde eğimin iyice azaldığı noktanın işaret ettiği sayıda faktör belirlenir. Scree analizine göre 1 ve 1'in üzerindeki öz değerler alındığından grafikten dokuzuncu faktörden itibaren çizgi grafiği eğimini kaybetmeye başladığı için faktör sayısı 9 ile sınırlanabilir (Şekil 2).

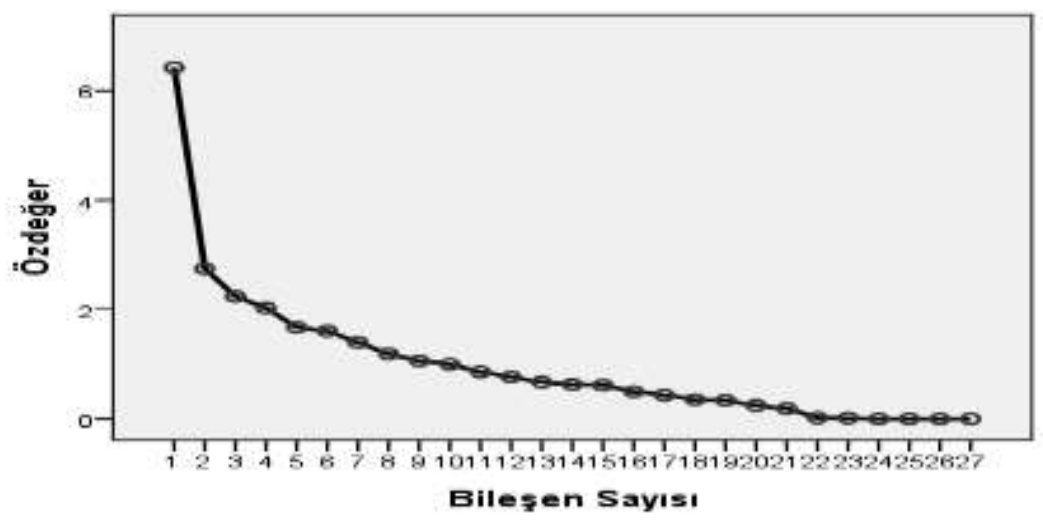

Şekil 2. Toprak parametrik ve morfolojik özelliklerine ilişkin faktör analizi çizgi grafiği

Çalışma alanına ait tüm toprak özelliklerinin öz değerleri Çizelge 2'de gösterilmiștir. Değişkenleri dönüştürmenin amacı, yorumlanması daha kolay anlamlı faktörler elde etmektir. Döndürülmüş bileşenler matrisi faktör analizinin nihai bir sonucudur. Matriste esas değişken ve onun faktörü arasındaki ilişkiler görülmektedir

Çizelge 2. Toprak parametrik ve morfolojik özelliklerine ilişkin dönüştürülmüş bileşenler matrisi

\begin{tabular}{cccc}
\hline Faktörler & Öz değer & \% Varyans & Birikimli \% varyans \\
\hline Faktör 1 & 4,91 & 18,19 & 18,19 \\
Faktör 2 & 2,90 & 10,76 & 28,95 \\
Faktör 3 & 2,70 & 10,0 & 38,95 \\
Faktör 4 & 2,05 & 7,61 & 46,57 \\
Faktör 5 & 1,66 & 6,16 & 52,73 \\
Faktör 6 & 1,63 & 6,07 & 58,80 \\
Faktör 7 & 1,52 & 5,65 & 64,45 \\
Faktör 8 & 1,52 & 5,63 & 70,09 \\
Faktör 9 & 1,43 & 5,31 & 75,40 \\
\hline
\end{tabular}

Faktör analizi sonucuna göre tüm toprak özellikleri arasında solma noktası en yüksek yükü kum ise en düșük yükü alarak atanan toprak özellikleri olmuștur (Çizelge 3). Faktör 1'e morfolojik değișkenler por boyutu, kök boyut, kök şekli, por şekli, kök sınıfı ve por sınıfı yüklenmiş olup, veri setine ait varyansın \%18'ini açıklamıștır. Faktör 1 'kök ve por faktörü' olarak adlandırılmıștır. Kök ve porlar arasında pozitif bir ilişki bulunmaktadır. Tokat Kazova'da 10 toprak indikatörü ile yapılan PCA analizi sonucunda araştırmacılar eigen değeri 1.0'in üzerinde olan 4 temel bileșen olduğunu bulmuşlardır. Yapılan araştırmada bu dört temel bileşen verideki değişkenliğin \%67,89'unu açıklamış olup, faktör 1 altında en yüksek ağırlığa sahip olan değişkenler potasyum, agregat stabilitesi, organik karbon ve hacim ağırlığı olmuştur (Acır, 2014). Rize'de yapılan benzer bir çalıșmada, araștırmacılar ekstrakte edilebilir Ca, Mg ve pH'nın atandığı Faktör 1'in toplam değişkenliğin \% 18,31'ini açıkladığını belirtmişlerdir. Aynı zamanda araştırmacılar, faktör 1'e atanan ekstrakte edilebilir $\mathrm{Ca}$ ve Mg'un $\mathrm{pH}$ ile pozitif ilişkili olması nedeniyle faktör, bazik katyonlar adıyla tanımlamışlardır (Özyazıcı ve ark., 2014).

Faktör 2'ye değişkenler silt, kil ve KDK yüklenmiş olup, Faktör 2 veri setine ilişkin varyansın \% 11'ini açıklamıştır (Çizelge 3). Faktör 2 'tekstür faktörü' olarak adlandırılmış ve beklenildiği üzere silt ve kil arasında negatif bir ilişki bulunmuştur. Faktör 3'e yapışkanlık, plastiklik ve hacim ağırlığı yüklenmiş olup, veri setine ait varyansın \% 10'unu açıklamıștır. Faktör 3 'toprak mekaniği faktörü' olarak adlandırılmıștır. Toprağın hacim ağırlığı, tekstür ve gözeneklilik ile yakından ilgilidir. Killi toprakların tanecik boyutu küçük olduğundan hacim ağırlığı da yüksektir. Hacim ağırlığı arttıkça su tutma kapasitesi ve nem artacağından, 
hacim ağırlığı yapışkanlık ve plastiklik ile pozitif ilişkilidir. Bu sebeple faktör 3'ün dolaylı olarak kil miktarı ve kil tipine bağlı olduğu söylenebilir.

Faktör 4'e bitkiye yarayışlı su içeriği ve tarla kapasitesi yüklenmiş olup, veri setine ait varyansın \% 7.61'ini açıklamıştır (Çizelge 3). Faktör 4 'toprak suyu faktörü' olarak adlandırılmıştır. Benzer bir çalışmada (Sağlam, 2013), araştırmacı, tarla kapasitesi, solma noktası ve kilin pozitif, makropor ve kum ise negatif ilişkiye sahip olduğunu rapor etmiş olup. birinci faktöre toprakta tutulan su miktarı üzerine olumlu ve olumsuz katkı yapabilen özellikler olması nedeniyle "toprak tekstürü ve suyu" adı vermiştir. Faktör 5’e örnekleme anındaki nem içeriği, konsantrasyonlar ve toprak organik maddesi yüklenmiş olup, veri setine ilişkin varyansın \% 6.16'sını açıklamıştır. Faktör 5 'redoksimorfik faktör' olarak adlandırılmıştır. Nem miktarının artması ile kil miktarında bir artıș olmaktadır, nitekim çalıșmada yapılan tanımlayıcı istatistik analizlerinin sonucu bunu destekler niteliktedir (Çizelge 1). Kil miktarının artması ile toprakta meydana gelen perkolasyon azalır ve burada kil kütanları yani konkresyonlar oluşmaktadır.

Çizelge 3 Toprak parametrik ve morfolojik özelliklerine ilişkin faktör analizi

\begin{tabular}{|c|c|c|c|c|c|c|c|c|c|}
\hline \multirow[b]{2}{*}{ Değișkenler } & \multicolumn{9}{|c|}{ Faktör } \\
\hline & 1 & 2 & 3 & 4 & 5 & 6 & 7 & 8 & 9 \\
\hline Por Boyut & 0,89 & & & & & & & & \\
\hline Por Şekli & 0,87 & & & & & & & & \\
\hline Kök Şekli & 0,87 & & & & & & & & \\
\hline Kök Boyut & 0,86 & & & & & & & & \\
\hline Por Sinıf & 0,81 & & & & & & & & \\
\hline Kök Sınıf & 0,81 & & & & & & & & \\
\hline Silt (\%) & & $-0,91$ & & & & & & & \\
\hline Kil (\%) & & 0,90 & & & & & & & \\
\hline KDK(meq/100gr) & & 0,88 & & & & & & & \\
\hline Yapışkanlık & & & 0,86 & & & & & & \\
\hline Plastiklik & & & 0,80 & & & & & & \\
\hline $\mathrm{D}_{\mathrm{b}}\left(\mathrm{g} / \mathrm{cm}^{3}\right)$ & & & 0,50 & & & & & & \\
\hline BYSİ (\%) & & & & 0,88 & & & & & \\
\hline TK (\%) & & & & 0,77 & & & & & \\
\hline \# Nem (\%) & & & & & 0,77 & & & & \\
\hline Konkresyon-nodül & & & & & 0,68 & & & & \\
\hline TOM (\%) & & & & & $-0,57$ & & & & \\
\hline Benekleşme & & & & & & 0,69 & & & \\
\hline $\mathrm{pH}$ & & & & & & 0,68 & & & \\
\hline $\mathrm{EC}(\mu \mathrm{S} / \mathrm{cm})$ & & & & & & $-0,60$ & & & \\
\hline Pedalite & & & & & & & 0,79 & & \\
\hline Kırılganlık & & & & & & & 0,56 & & \\
\hline $\operatorname{Kum}(\%)$ & & & & & & & $-0,39$ & & \\
\hline SN (\%) & & & & & & & & 0,94 & \\
\hline $\mathrm{CaCO}_{3}(\%)$ & & & & & & & & & 0,68 \\
\hline $\mathrm{Ks}(\mathrm{cm} / \mathrm{s})$ & & & & & & & & & $-0,52$ \\
\hline AS (\%) & & & & & & & & & 0,50 \\
\hline \% Varyans & 18,19 & 10,76 & 10 & 7,61 & 6,16 & 6,07 & 5,65 & 5,63 & 5,31 \\
\hline
\end{tabular}

TOM: Toprak Organik Maddesi, Db: Hacim Ağırlığı, = Örnekleme Anındaki Su İçeriği, AS: Agregat Stabilitesi, TK: Tarla Kapasitesi, SN: Solma Noktası, BYSİ: Bitkiye Yarayışlı Su İçeriği, Ks: Doymuş Hidrolik İletkenlik, KDK: Katyon Değiişim Kapasitesi, İH: İnfiltrasyon Hızı

Faktör 6'ya benekleşme, EC ve pH yüklenmiş olup, veri setine ait varyansın \% 6.07'sını açılamıştır. Faktör 6 'toprak kimyası faktörü' olarak adlandırılmıştır. Benekleşme ve elektriksel iletkenlik arasında negatif bir ilişki vardır. EC'nin düşük olduğu topraklarda $K_{s}$ daha yüksektir. Benekleşme suyun haraketi ve kil ile ilişkili bir morfolojik toprak özelliğidir. Nitekim çalışmamızda $\mathrm{K}_{\mathrm{s}}$ ile EC arasında 0.05 önem seviyesinde negatif bir ilişki bulunmuş olup, redoksimorfik özelliklerden olan beneklenmenin (mottles) EC'nin düşük olduğu yerlerde fazla olmasını kanıtlar niteliktedir. EC'nin düşük olduğu sıkıșmış katmanlarda su hareketinin bir sonucu olarak beneklenmenin görülmesi sonuçları destekler niteliktedir. Faktör 7'e pedalite, kırılganlık ve kum yüklenmiş olup, veri setine ait varyansın \% 6.65'ini açıklamıştır. Faktör 7 'pedalite ve kıvam faktörü' olarak adlandırılmıştır. Kumun artması ile toprağın su tutma kapasitesi azalarak, kıvam limitindeki su miktarı da buna bağlı olarak azaltmaktadır. Faktör 8'e solma noktası tek başına yüklenmiş olup, veri setine ait varyansın \% 5.63'ünü açılklamıştır. Faktör 8 'su tutma faktörü' olarak adlandırılmıştır. Faktör 9'a $\mathrm{CaCO}_{3}, \mathrm{~K}_{\mathrm{s}}$ ve \% agregat stabilitesi yüklenmiş olup, veri setine ait varyansın \% 5.31'ini 
açılklamıştır. Faktör 9 'toprak suyu hareketi ve strüktür faktörü' olarak adlandırılmıştır. $\mathrm{CaCO}_{3}$ ve Ks arasındaki negatif ilişki beklenen bir durumdur.

\section{Sonuçlar}

Faktör analizi sonuçlarına göre, çalışma alanındaki toprak değişkenliğinin temel olarak kök sınıfı/boyut/şekil, gözenek sınıfı/boyut/şekil ve doku bileşenlerinden kaynaklandığı söylenebilir. $\mathrm{Bu}$, çalışma alanındaki hidropedolojik özelliklerin değişimini kontrol eden en önemli değişkenlerin gözenek ve kök özellikleri olduğunu düşündürmüştür. Hidropedolojiyi daha iyi anlamak için yüzey altında meydana gelen süreçleri ve bu süreçlerin yeterli ve etkili toprak-su yönetimi üzerindeki etkilerini anlamak gerekir. Yüzey altında gerçekleşen süreçler, toprak oluşumu, toprak hidrolojisi ve hidrofiziksel süreçler üzerinde büyük bir kontrole sahiptir. Bu aşamada gerçekleşen iki yönlü geri-besleme mekanizmalarının anlaşılması oldukça önemlidir. Yapılan bu çalışmada geçirimsiz tabaka ile üst toprak ara yüzünde meydana gelen yatay akışın, baskın hidrolojik süreç olduğu düşünülmektedir.

\section{KAYNAKLAR}

Acir, N., 2014. Kurak ve yarı-kurak bölge topraklarının toprak kalitesinin belirlenmesinde kullanılacak minimum veri setlerinin hazırlanması. Gaziosmanpaşa Üniversitesi, Fen Bilimleri Enstitüsü. Toprak Bilimi ve Bitki Besleme Ana Bilim Dall, Tokat. (Doktora Tezi).

Anonim a,2021.http://cografyaharita.com/turkiye_mulki_idare_haritalari.html

Anonim b,2021 https://earth.google.com/web/search

Birgili, S, R Yoldas and G Unalan 1975. Çankiri-Çorum havzasinin jeolojisi ve petrol olanaklari. MTA Raporu.

Blake, G., Hartge, K., 1986. Bulk density. Methods of soil analysis. Phys. Mineral. methods. Physical and Mineralogical Methods: 377-382.

Cassel, DK and DR Nielsen 1986. Field capacity and available water capacity. Methods of Soil Analysis: Part 1-Physical and Mineralogical Methods: 901-926.

Chapman, HD and PF Pratt 1982. Method for the Analysis of Soil. Plant And Water 2nd ed California University Agricultural Division, California: 170.

Çelenk, Fehmiye Kadıŏulları 2016. Toprak özelliklerinde mekânsal değişkenliğin faktör analizi: Erenler örneği (Sakarya). Türk Coğrafya Dergisi.

Doğan, Uğur 2002. Çankırı doğusunda jips karstlaşmasıyla oluşan sübsidans dolinleri. Gazi Üniversitesi Gazi Eğitim Fakültesi Dergisi 22.

Donkin, MJ and MV Fey 1991. Factor analysis of familiar properties of some Natal soils with potential for afforestation. Geoderma 48: 297-304.

Erşahin, S 1999a. Aluviyal bir tarlada bazı fiziksel ve kimyasal toprak özelliklerinin uzaysal (Spatial) değişkenliğinin belirlenmesi. Selçuk Üniversitesi Ziraat Fakültesi Dergisi 13: 34-41.

Erşahin, S and MR Karaman 2000. Toprak Değişkenliğinin Yere Özgü Amenajman ve Toprak Verimliliği Çalışmaları için Değerlendirilmesinde Faktör Analizinin Kullanılması. Tarım Bilimleri Dergisi 6: 76-81.

Gee G.W., ve Bauder, J.W. 1986., 1986. Particle-Size Analysis. . 2nd ed. Am. Soc. Agron., Madison, WI: 383412.

Hendershot, W.H., Lalande, H. ve Duquette, M., 1993. Soil Reaction and Exchangeable Acidity. Can. Soc. Soil Sci. CRC Pres Inc. Boca Raton, Florida. USA.

Janzen, H.H., 1993, 1993. Soluble Salts in Soil Sampling and Methods of Analysis. Cart. M.R. Can. Soc. Soil Sci. CRC Pres Inc. Boca Raton, Florida. USA.

Kacar, B 1996. Toprak analizleri.(soil analysis) AÜ Ziraat Fakültesi Egitim Arastırma ve Gelistirme Vakfi Publications No: 3. In Toprak analizleri.(soil analysis) AÜ Ziraat Fakültesi Egitim Arastırma ve Gelistirme Vakfi Publications No: 3: Ankara.

Kemper, W.D., Rosenau, R.C., 1986. Aggregate Stability and Size Dlstributlon'. Methods soil Anal. Part 1 Phys. Mineral. Methods. p 425-42.

Klute, A., Cassel, D.K., Nielsen, D.R., 1986. Field Capacity and Available Water Capacity. 635-660. https://doi.org/10.2136/sssabookser5.1.2ed.c36

Mayor, Ángeles G, Susana Bautista and Juan Bellot 2009. Factors and interactions controlling infiltration, runoff, and soil loss at the microscale in a patchy Mediterranean semiarid landscape. Earth Surface Processes and Landforms 34: 1702-1711.

McGrath, David, Chaosheng Zhang and Owen T Carton 2004. Geostatistical analyses and hazard assessment on soil lead in Silvermines area, Ireland. Environmental Pollution 127: 239-248.

McNeal, James M, RC Severson and LARRY P GouGH 1985. The occurrence of extractable elements in soils from the northern Great Plains. Soil Science Society of America Journal 49: 873-881. 
Mulla, DJ and AB McBratney 2000. Soil spatial variability. p. A321-A352. MK Summer (ed.) Handbook of soil science. In Soil spatial variability. p. A321-A352. MK Summer (ed.) Handbook of soil science: CRC Press, Boca Raton, FL. Soil spatial variability. p. A321-A352. In MK Summer (ed.) Handbook of soil science. CRC Press, Boca Raton, FL.

Nizam, A, D Kleinbaum, K Muller and L Kupper 1998. Applied regression analysis and other multivariable methods. Duxbury Pr, Pacific Grove.

Nelson, D.W., ve Sommers, L.E., 1982. Total Carbon, organic carbon, and Organic Matter. Page, A.L. Methods Soil Anal. Part 2, 2nd ed. Agron. Monogr. 9. ASA. Madison, 539-579.

Özyazici, M.A., Sağlam, M., Dengiz, O., Erkoçak, A. 2014. Toprak Su Dergisi 3 (1):(12-23).

Park, SJ and TP Burt 1999. Identification of throughflow using the distribution of secondary iron oxides in soils. Geoderma 93: 61-84.

Reynolds, Wd and De Elrick 1985. In Situ Measurement Of Field-Saturated Hydraulic Conductivity, Sorptivity, And The [Alpha]-Parameter Using The Guelph Permeameter. Soil Science 140: 292-302.

Sağlam, Mustafa 2013. Çok değişkenli istatistiksel yöntemler ile toprak özelliklerinin gruplandırılması. Toprak Su Dergisi 2.

Sağlam, Mustafa 2015. Evaluation of the physicochemical properties of alluvial and colluvial soils formed under ustic moisture regime using multivariate geostatistical techniques. Archives of Agronomy and Soil Science 61: 943-957.

Sánchez-Marañón, M, R Delgado, J Párraga and G Delgado 1996. Multivariate analysis in the quantitative evaluation of soils for reforestation in the Sierra Nevada (southern Spain). Geoderma 69: 233-248.

Shukla, MK, R Lal and M Ebinger 2006. Determining soil quality indicators by factor analysis. Soil and tillage research 87: 194-204.

Sivapalan, Murugesu 2003. Process complexity at hillslope scale, process simplicity at the watershed scale: is there a connection? Hydrological Processes 17: 1037-1041.

Webster, Richard and Margaret A Oliver 2001. Geostatistics for environmental scientists (Statistics in Practice). 